\title{
FURTHER STUDIES OF 35-40-NM VIRUS-LIKE PARTICLES ASSOCIATED WITH OUTBREAKS OF ACUTE GASTROENTERITIS
}

\author{
K. Taniguchi, S. Urasawa and Tomoko Urasawa \\ Department of Hygiene, Sapporo Medical College, Sapporo, 060 Japan
}

Plates III-V

Summary. Virus-like particles similar in size and morphology to the Otofuke agent, which was detected first in an institutional outbreak of acute gastroenteritis at Otofuke, Hokkaido, Japan in 1978, were again observed in faeces from patients in four other outbreaks of acute gastroenteritis in Hokkaido.

In each of three outbreaks in which the faeces and paired sera of patients were available, apparent sero-responses against the particles obtained in corresponding outbreaks were confirmed. Serological analysis of the particles from five separate epidemics by immune electronmicroscopy suggested that the particles from these epidemics may be related antigenically to one another.

Besides the above-mentioned particles measuring $35-40 \mathrm{~nm}$ in diameter, 15-20-nm "empty" particles were also found in the stool specimens obtained from two of the five epidemics. In addition, serological cross reactivity between these two kinds of particles was observed.

These findings provide further support for the aetiological role of the 35-40-nm particles (Otofuke agent-like particles) in acute gastroenteritis in older children and adults.

\section{INTRODUCTION}

Various small round virus-like particles ranging in size from 22 to $30 \mathrm{~nm}$ have been described as putative pathogens for acute non-bacterial gastroenteritis in man. Some of them are reported to have been associated with community outbreaks of gastroenteritis. They may be divided into three groups: 1) parvovirus-like particles, 2) caliciviruses and 3) astroviruses. Parvovirus-like particles measure $25-27 \mathrm{~nm}$ in diameter and have a buoyant density of $1.38-1.40 \mathrm{~g} / \mathrm{ml}$ in $\mathrm{CsCl}$. In this group may be included multiple antigenic types such as Norwalk, Montgomery County, Hawaii, W, Ditchling and Cockle agents (Clarke et al., 1972; Appleton and Pereira, 1977; Appleton et al., 1977; Thornhill et al., 1977; Dolin, 1978). Caliciviruses are $30 \mathrm{~nm}$ in diameter, having a feathery edge and a six-pointed star with a central hollow (Madeley 
and Cosgrove, 1976; McSwiggan, Cubitt and Moore, 1978). Astroviruses, having a diameter of $28 \mathrm{~nm}$, are characterised by a smooth edge and a five- or six-pointed star with no central hollow (Madeley and Cosgrove, 1975; Ashley, Caul and Paver, 1978).

Besides these agents, small round virus-like particles with smooth or feathery outlines have been described (Holmes, 1979; Madeley, 1979). Detailed studies of the aetiological role of these particles and their properties have not yet been made.

As previously reported (Taniguchi, Urasawa and Urasawa, 1979), we found 35-40-nm particles in the stools of patients in an outbreak of gastroenteritis at Otofuke, Hokkaido, in 1978. The particles (Otofuke agent) had an alternating arrangement of 10 each of two kinds of capsomeres (round and rod-shaped) on the periphery and had a buoyant density of $1.35-1.37 \mathrm{~g} / \mathrm{ml}$ in $\mathrm{CsCl}$. During studies on epidemics of acute gastroenteritis which occurred later in Hokkaido, similar particles (Otofuke agent-like particles) were detected in four more outbreaks. We have compared, by immune electronmicroscopy (IEM), the particles from five distinct outbreaks and have also detected 15-20-nm "empty" particles, which seemed to be antigenically related to the $35-40-\mathrm{nm}$ particles.

\section{MATERIALS AND METHODS}

Faeces. Faecal specimens were collected from patients 1 or 2 days after the onset of gastroenteritis and stored at $-80^{\circ} \mathrm{C}$ until used. About $20 \%(\mathrm{w} / \mathrm{v})$ faecal suspensions were made in Eagle's minimal essential medium and clarified by centrifugation at $3000 \cdot g$ for $30 \mathrm{~min}$. Of each suspension, $3 \mathrm{ml}$ was layered on to $7 \mathrm{ml}$ of $25 \%$ (w/v) sucrose in $10 \mathrm{~mm}$ phosphate buffered saline

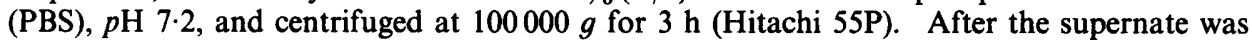
discarded, the centrifuged tube was rinsed gently with $10 \mathrm{mM}$ phosphate buffer (PB), $p \mathrm{H} 7 \cdot 2$, to remove remaining sucrose. The resultant pellet was suspended in $0.3 \mathrm{ml}$ of $10 \mathrm{~mm} P B$. This concentrated suspension was used for examination by EM and IEM.

Electronmicroscopy and immune electronmicroscopy. EM examination was as previously described (Taniguchi et al., 1979). IEM was performed by mixing $0.05 \mathrm{ml}$ of concentrated virus suspension with $0.05 \mathrm{ml}$ of a 1 in 25 or 1 in 150 dilution of serum. After incubation at room temperature for $1 \mathrm{~h}$, the mixture was centrifuged at $50000 \mathrm{~g}$ for $1 \mathrm{~h}$ with an RPS50 (Hitachi) swing-out rotor. The pellet or sediment was resuspended in a drop of distilled water, mixed with an equal volume of $3 \%(w / v)$ phosphotungstic acid $(p \mathrm{H} \mathrm{7.0)}$ and applied to a carbon-collodioncoated 400 mesh EM grid. Preparations were examined in a Hitachi H500 electron microscope.

All IEM experiments were performed with randomised, coded samples. Antibody content in each serum sample was rated in the range 0 to 4 by judging the amount of antibody coating the particles. A change of 1 or greater in rating was considered significant.

Isopycnic banding of the 35-40-nm particles in CsCl density gradient. Thirty $\mathrm{ml}$ of $20 \%$ (w/v) stool suspension of patient no. 20 in outbreak no. 5 (table II) was processed by treatment with trifluorotrichloroethane and ultracentrifugation on $25 \%$ sucrose. To $4 \mathrm{ml}$ of the concentrated suspension in $10 \mathrm{~mm}$ PBS, CsCl was added to make a density of $1.35 \mathrm{~g} / \mathrm{ml}$. Then, the suspension was centrifuged at $4^{\circ} \mathrm{C}$ for $18 \mathrm{~h}$ at $40000 \mathrm{rpm}$ with the RPS50 rotor. Fractions were collected in $0 \cdot 2-\mathrm{ml}$ volumes and examined by IEM for the presence of particles. The procedure for IEM examination was as described previously (Taniguchi et al., 1979) except for the use of a 1 in 400 dilution of the convalescent serum of patient no. 23 in outbreak no. 5 as the antibody source in IEM.

Preparation of $H$ antigen of poliovirus. $\mathrm{H}$ antigen of poliovirus type 1 (Mahoney strain) was prepared as described previously (Urasawa, Urasawa and Taniguchi, 1979). 
Preparation of antiserum against the 35-40-nm particles. The 35-40-nm particles were purified from $50 \mathrm{ml}$ of $20 \%$ (w/v) stool suspension from patient no. 20 in outbreak no. 5 by low-speed centrifugation, precipitation by polyethylene glycol, treatment with trifluorotrichloroethane, ultracentrifugation in $25 \%$ sucrose followed by a $\mathrm{CsCl}$ banding and two cycles of sucrose density-gradient centrifugation. The degree of purification and the quantity of the particles in each step were checked by EM.

Antiserum to the 35-40-nm particles was prepared by injection of purified particles mixed with an equal volume of Freund's complete adjuvant into a guinea-pig. Of this mixture, $1 \mathrm{ml}$ was inoculated into footpads and each hind leg intramuscularly, and a booster dose of the same preparation was given 5 weeks after the first inoculation.

Preparation of feline calicivirus for EM examination. The F4 (KN2-0) strain of feline calicivirus (Takahashi, Konishi and Ogata, 1971) was grown in primary feline kidney-cell culture prepared as described by Youngner (1954). Infected tissue-culture fluid was harvested 18 $h$ after virus inoculation and clarified by low-speed centrifugation. The virus was concentrated by subsequent ultracentrifugation, and the pellet was suspended in $10 \mathrm{~mm}$ PB. The suspension was layered on to $25 \%$ sucrose and processed for EM as described above.

\section{RESULTS}

\section{Outline of five outbreaks of gastroenteritis}

Specimens obtained from five outbreaks of acute gastroenteritis were investigated. Main clinical symptoms and attack rates in each outbreak are shown in table I. Routine bacteriological examinations revealed no pathogen in any of the outbreaks. Epidemiological inquiries failed to reveal a mode of spread. In all of the outbreaks, acute-phase stool specimens were available, and paired sera were obtained except from outbreak no. 2 .

\section{Electronmicroscopy}

As described previously (Taniguchi et al., 1979), in outbreak no. 1 35-40-nm particles were seen in specimens from five of seven patients examined. These particles were previously named Otofuke agent after the location of the institution where the outbreak occurred. In outbreak no. 2, similar particles were detected in six of 31 patients. In one (derived from patient no. 9) of the six stool specimens positive for the particles, coronavirus-like particles were also observed (fig. 1). They showed marked pleomorphism, possessed 20-30-nm petal-shaped surface projections typical of coronaviruses, and ranged in size from 150 to $450 \mathrm{~nm}$ inclusive of the projections. One stool suspension negative for the 35-40-nm particles (derived from patient no. 29) contained a relatively large quantity (about 50 particles per square of EM grid) of round particles of about $30 \mathrm{~nm}$ resembling astrovirus (fig. 2). Similarly, in outbreaks nos. 3 and 4, the 35-40-nm particles were found in three of eight and three of seven specimens respectively. However, the number of particles observed in outbreak no. 3 was too small to be used for IEM (c. 40-50 particles per EM grid). Outbreak no. 5 occurred in the Kino district adjacent to the Shimo-otofuke district in the Otofuke area where outbreak no. 1 had occurred. Similar particles were again detected in nine of 15 stool specimens, and in large quantities in four of the nine positive specimens. 
TABLE I

Outbreaks of acute gastroenteritis associated with 35-40-nm virus-like particles

\begin{tabular}{|c|c|c|c|c|c|c|c|c|c|}
\hline $\begin{array}{l}\text { Outbreak } \\
\text { no. }\end{array}$ & Date & District & Institution & $\begin{array}{l}\text { Age of } \\
\text { patients } \\
\text { (years) }\end{array}$ & $\begin{array}{c}\text { Number ill/ } \\
\text { number at } \\
\text { risk }(\%)\end{array}$ & vomiting & $\begin{array}{l}\text { rcentage of } p \\
\text { abdominal } \\
\text { pain }\end{array}$ & atients with & fever \\
\hline $1^{*}$ & $\begin{array}{l}11-18 \text { Apr. } \\
1978\end{array}$ & $\begin{array}{l}\text { Otofuke } \\
\text { (Shimo-otofuke) }\end{array}$ & $\begin{array}{l}\text { Institution for } \\
\text { the mentally retarded }\end{array}$ & $\begin{array}{l}\text { İnmates } \\
(22-51) \\
\text { Staff } \\
(26-44)\end{array}$ & $\left.\begin{array}{c}32 / 92 \\
(35) \\
2 / 32 \\
(6)\end{array}\right\}$ & 74 & 12 & 38 & 6 \\
\hline 2 & $\begin{array}{c}15-25 \text { Dec. } \\
1978\end{array}$ & Kitami & $\begin{array}{l}\text { Elementary } \\
\text { school }\end{array}$ & $\begin{array}{l}\text { Pupils } \\
(6-12)\end{array}$ & $\begin{array}{l}550 / 1224 \\
(45)\end{array}$ & NK & NK & NK & NK \\
\hline 3 & $\begin{array}{c}20-27 \text { Jan. } \\
1979\end{array}$ & Bibai & $\begin{array}{l}\text { Boarding house of } \\
\text { school for handicapped } \\
\text { children }\end{array}$ & $\begin{array}{c}\text { Inmates } \\
(7-15)\end{array}$ & $\begin{array}{c}14 / 66 \\
(21)\end{array}$ & 64 & 71 & 21 & NK \\
\hline 4 & $\begin{array}{c}15-22 \text { Feb. } \\
1979\end{array}$ & Horonobe & $\begin{array}{l}\text { Institution for } \\
\text { the mentally retarded }\end{array}$ & $\begin{array}{l}\text { Inmates } \\
(17-50) \\
\text { Staff } \\
(22-43)\end{array}$ & $\begin{array}{c}44 / 97 \\
(45) \\
12 / 35 \\
(34)\end{array}$ & 45 & 32 & 37 & 29 \\
\hline 5 & $\begin{array}{l}28 \text { May.- } \\
16 \text { Jul. } \\
1979\end{array}$ & $\begin{array}{l}\text { Otofuke } \\
\text { (Kino) }\end{array}$ & $\begin{array}{l}\text { Two elementary } \\
\text { schools and two } \\
\text { junior high schools }\end{array}$ & $\begin{array}{l}\text { Pupils } \\
(6-15) \\
\text { Staff } \\
(23-54)\end{array}$ & $\left.\begin{array}{c}1174 / 1734 \\
(68) \\
21 / 114 \\
(18)\end{array}\right\}$ & 78 & 71 & 42 & 32 \\
\hline
\end{tabular}

NK = Not known.

* Data from Taniguchi et al. (1979). 
V'IRUS ASSOCIATED WITH GASTROENTERITIS
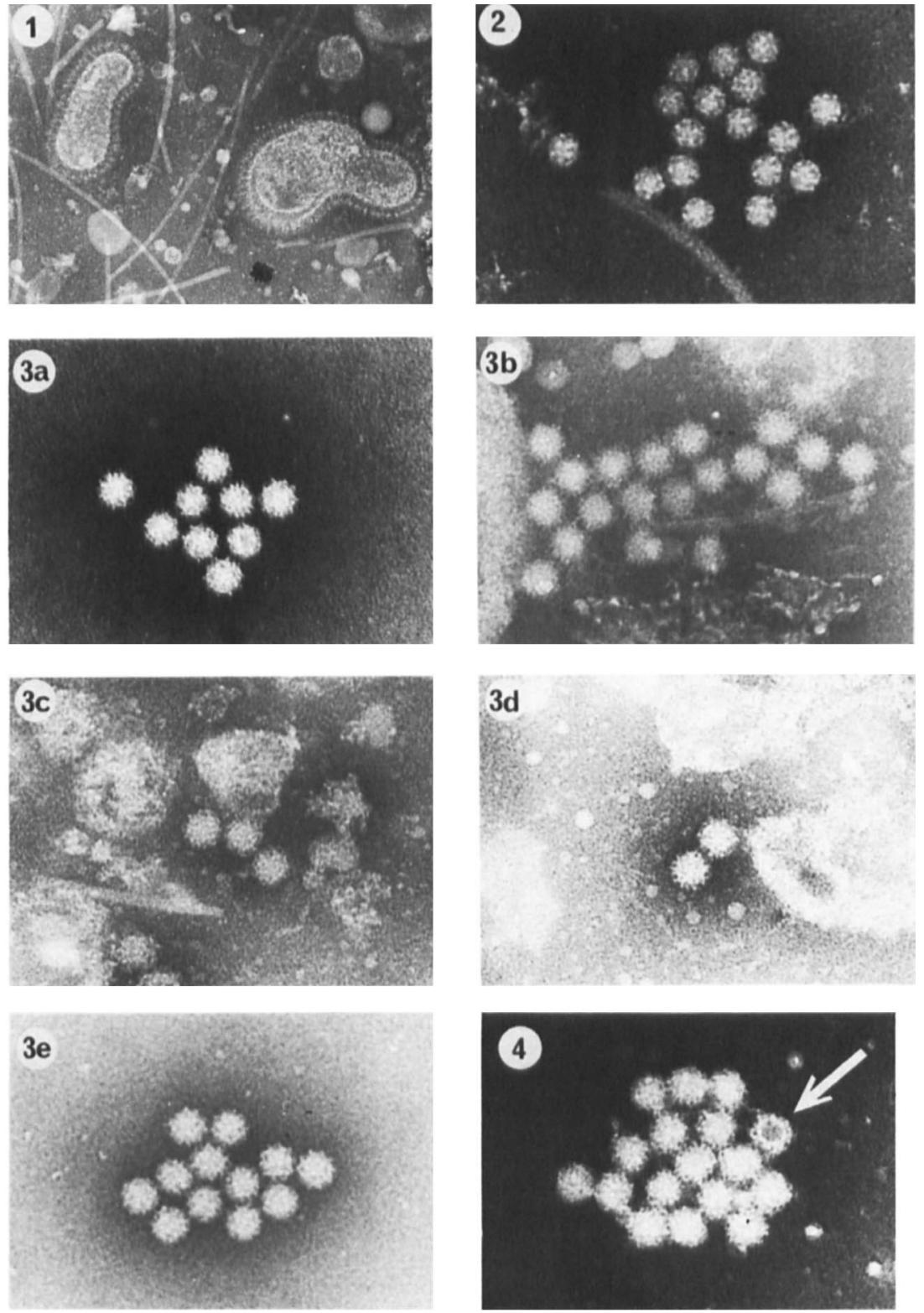

FIG. 1.-Coronavirus-like particles detected in a stool specimen from patient no. 9 in outbreak no. 2 . Phosphotungstic acid (PTA). $\times 48750$.

FIG. 2.-Astrovirus-like particles detected in a stool specimen from patient no. 29 in outbreak no. 2. PTA. $\times 126750$.

Figs. 3a-e.-Representative electron micrographs of the 35-40-nm particles from each of five outbreaks. (a) outbreak no. 1, (b) outbreak no. 2, (c) outbreak no. 3, (d) outbreak no. 4, and (e) outbreak no. 5. PTA. $\times 126750$.

FIG. 4.-A 35-40-nm "empty" particle (arrow) found by immune electronmicroscopy with a stool specimen from outbreak no. 5 and a convalescent serum from the same incident. PTA. $\times 126750$. 
TABLE II

Detection of 35-40-nm particles

\begin{tabular}{|c|c|c|}
\hline Outbreak no. & $\begin{array}{c}\text { Number of } \\
\text { stool specimens } \\
\text { examined }\end{array}$ & $\begin{array}{l}\text { Number of stool } \\
\text { specimens positive for the } \\
\text { particles (and identification } \\
\text { nos. of patients) }\end{array}$ \\
\hline $1^{*}$ & 7 & \multirow{5}{*}{$\begin{array}{c}5 \\
(1,2,3,4,5) \\
6 \\
(6,7,8,9,10,11) \\
3 \\
(12,13,14) \\
3 \\
(15,16,17) \\
9 \\
(18,19,20,21,22,23 \\
24,25,26)\end{array}$} \\
\hline 2 & 30 & \\
\hline 3 & 8 & \\
\hline 4 & 7 & \\
\hline 5 & 15 & \\
\hline
\end{tabular}

* Data from Taniguchi et al. (1979).

The above results are summarised in table II, and representative pictures of the 35-40-nm particles in the respective outbreaks are shown in figs. 3a-e.

\section{Immune electronmicroscopy}

IEM was used to confirm the antibody response of patients against the 35-40-nm particles. Fortunately for IEM tests, these particles usually occurred singly without antibody coating. In a preliminary experiment, the ratings in IEM tests were examined with five different dilutions of the convalescent serum of patient no. 23 in outbreak no. 5 (table III). A change in rating was clearly seen depending on the dilution of serum. Based on this result, a 1 in 25 dilution of serum was routinely used in the following IEM tests. A 1 in 150 dilution of serum was also examined when acute-phase serum had a large amount of pre-existing antibody (rating of 3-4 or 4) against the particles.

In outbreaks nos. 1, 4 and 5, in which large enough amounts of 35-40-nm

TABLE III

Titration of paired acute- and convalescent-phase sera (from patient no. 23) with the 35-40-nm particles (from patient no. 20) by immune electronmicroscopy

\begin{tabular}{|c|c|c|}
\hline \multirow{2}{*}{$\begin{array}{l}\text { Dilution of } \\
\text { serum: } \\
1 \text { in } \\
\end{array}$} & \multicolumn{2}{|c|}{ Rating* of } \\
\hline & $\begin{array}{l}\text { acute } \\
\text { serum }\end{array}$ & $\begin{array}{c}\text { convalescent } \\
\text { serum }\end{array}$ \\
\hline 8 & NT & 4 \\
\hline 25 & $0-1$ & 4 \\
\hline 400 & NT & $\begin{array}{l}2-3 \\
0-1\end{array}$ \\
\hline 1600 & NT & 0 \\
\hline
\end{tabular}

$\mathrm{NT}=$ not tested.

* Antibody coating of the 35-40-nm particles was assessed on a scale 0 to 4 . 
particles and paired sera were available, rises of antibody in convalescentphase sera were quite evident against the particles obtained from the respective outbreaks, as seen in table IV.

Results of serological comparison among the particles detected in the five separate epidemics are also shown in table IV. Both sets of paired sera from outbreak no. 3 and one set each of paired sera from outbreaks nos. 4 and 5 showed significant antibody responses in IEM tests with the particles detected in outbreak no. 1. Significant serological responses against the particles from outbreak no. 2 were confirmed in both sets of paired sera from outbreak no. 1 and one set from outbreak no. 3, with a similar response against the particles from outbreak no. 4 being found in both sets of paired sera from outbreak no. 1. Furthermore, IEM tests on the particles from outbreak no. 5 revealed significant antibody responses in one set each of paired sera from outbreaks nos. 1 and 3, and the two sets from outbreak no. 4.

In an IEM test with the stool suspension containing the 35-40-nm particles and coronavirus-like particles, the latter were not agglutinated by any of the paired sera from the patients in outbreaks nos. 3 and 4 , which, as described above, had significant seroresponses against the 35-40-nm particles. Likewise, in an IEM test on the astrovirus-like particles, no paired sera from outbreaks nos. 1, 3 and 5 showed significant antibody responses against the particles.

The reaction of the 35-40-nm particles derived from patient no. 20 in outbreak no. 5 was examined in IEM tests with antisera against the Norwalk agent, the Hawaii agent, the $\mathrm{W}$ agent and calicivirus-like particles. As shown in table $\mathrm{V}$, there was no evidence for antigenic cross reactivity between the 35-40-nm particle and those gastroenteritis viruses.

\section{Isolation and characterisation of 35-40-nm particles and 15-20-nm "empty" particles}

The 35-40-nm particles seemed to be morphologically stable, because "empty" particles without an internal core of similar size were rarely encountered in stool specimens (fig. 4) and, even after heat treatment $\left(60^{\circ} \mathrm{C}, 30 \mathrm{~min}\right)$, there were few empty particles.

On the other hand, small "empty" particles penetrated by staining solution measuring $15-20 \mathrm{~nm}$ in diameter were often seen in the virus-antibody complexes in IEM tests on the stool specimens from outbreaks nos. 4 and 5 (fig. 5). In $\mathrm{CsCl}$ density-gradient centrifugation, the 15-20-nm empty particles banded as a single peak with a buoyant density of approximately $1.28 \mathrm{~g} / \mathrm{ml}$, whereas the 35-40-nm particles showed a peak at $1.37 \mathrm{~g} / \mathrm{ml}$ with a shoulder (fig. 6). The 35-40-nm particles and the 15-20-nm empty particles that agglutinated with a convalescent serum are shown in figs. $7 a$ and $b$.

Next, to elucidate the antigenic relationship between these two kinds of particles, an experiment was undertaken on the assumption that if the particles were antigenically distinct, their successive addition to a convalescent serum might separate them into different aggregates. The 35-40-nm particles and the 15-20-nm empty particles purified by $\mathrm{CsCl}$ density-gradient centrifugation 
TABLE IV

Serological reaction of paired sera from four outbreaks with 35-40-nm particles from other outbreaks in immune electronmicroscopy

\begin{tabular}{|c|c|c|c|c|}
\hline \multirow[b]{3}{*}{$\begin{array}{c}\text { Source of } \\
\text { stool suspension }\end{array}$} & \multicolumn{4}{|c|}{ Rating* of antibody response in tests with paired sera from indicated patients in } \\
\hline & outbreak no. 1 & outbreak no. 3 & outbreak no. 4 & outbreak no. 5 \\
\hline & $\begin{array}{lc}\text { Acute } \\
\text { serum }\end{array} \begin{array}{c}\text { Convalescent } \\
\text { serum }\end{array}$ & $\begin{array}{lc}\text { Acute } & \text { Convalescent } \\
\text { serum } & \text { serum } \\
\end{array}$ & $\begin{array}{lc}\begin{array}{l}\text { Acute } \\
\text { serum }\end{array} & \begin{array}{c}\text { Convalescent } \\
\text { serum }\end{array} \\
\end{array}$ & $\begin{array}{lc}\text { Acute } & \begin{array}{c}\text { Convalescent } \\
\text { serum }\end{array} \\
\end{array}$ \\
\hline $\begin{array}{l}\text { Outbreak no. } 1 \text {, } \\
\text { patient no. } 3\end{array}$ & $\begin{array}{l}\text { Patient no. } 1 \\
\text { Patient no. } 4 \\
3\end{array}$ & $\begin{array}{l}\text { Patient no. } 13 \\
\begin{array}{l}2-3 \\
\text { Patient no. } 30 \\
1\end{array}\end{array}$ & $\begin{array}{cc}\text { Patient no. } 16 \\
1 & 3-4 \\
\text { Patient no. } 17 & 2\end{array}$ & $\begin{array}{l}\text { Patient no. } 20 \\
3-4 \\
\text { Patient no. } 33 \\
2-3\end{array}$ \\
\hline $\begin{array}{l}\text { Outbreak no. } 2 \\
\text { patient no. } 9\end{array}$ & 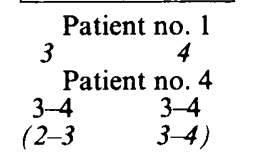 & 1 Patient no. 13 & $\begin{array}{l}\text { Patient no. } 16 \\
\begin{array}{l}2-3 \\
\text { Patient no. } 17\end{array} \\
4\end{array}$ & $4 \begin{array}{l}\text { Patient no. } 33 \\
3-4\end{array}$ \\
\hline $\begin{array}{r}\text { Outbreak no. } 4 \text {, } \\
\text { patient no. } 16\end{array}$ & 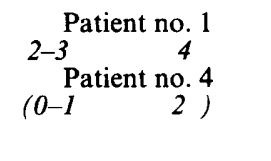 & $\begin{array}{cc}\text { Patient no. } 13 \\
3 & 3-4 \\
\text { Patient no. } 30 \\
4 & 4 \\
(2 & 1-2)\end{array}$ & $\begin{array}{l}\text { Patient no. } 16 \\
1-2 \\
3\end{array}$ & $\begin{array}{l}4_{2-3}^{\text {Patient no. } 20} \\
\text { Patient no. } 33 \\
2\end{array}$ \\
\hline $\begin{array}{r}\text { Outbreak no. } 5 \text {, } \\
\text { patient no. } 20\end{array}$ & 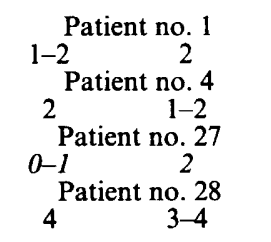 & 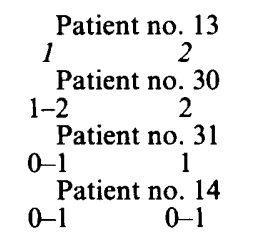 & 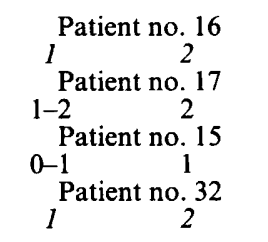 & $\begin{array}{cc}\text { Patient no. } 20 \\
1 & 3-4 \\
\text { Patient no. } 23 \\
0-1 & 4 \\
\text { Patient no. } 33 \\
0 & 3-4 \\
\text { Patient no. } 18 \\
1 & 4\end{array}$ \\
\hline
\end{tabular}

*Antibody coating of the 35-40-nm particles was assessed on a scale 0 to 4 . Entries in italics indicate significant response; entries in boxes indicate reactions between the particles and patients' sera from the same outbreaks; entries in parentheses indicates tests with a 1 in 150 dilution of serum. Convalescent sera were obtained 2 to 3 weeks after the onset of illness. 
TABLE V

Serological comparison of the 35-40-nm particles, from patient no. 20 in outbreak no. 5, with some other agents by immune electronmicroscopy

\begin{tabular}{l|cc}
\hline \multicolumn{1}{c|}{$\begin{array}{c}\text { Paired sera* } \\
\text { against }\end{array}$} & $\begin{array}{c}\text { Rating } \dagger \text { of } \\
\begin{array}{c}\text { pre-illness or convalescent } \\
\text { acute serum }\end{array}\end{array}$ \\
\hline $\begin{array}{l}\text { W agent (volunteer) } \\
\text { sorum }\end{array}$ \\
$\begin{array}{l}\text { Norwalk agent (chimpanzee) } \\
\text { Horwalk agent (patient) }\end{array}$ & 0 & 0 \\
Hawaii agent (volunteer) & $1-2$ & $1-2$ \\
Calicivirus (patient) & 1 & $1-2$ \\
\hline
\end{tabular}

\footnotetext{
* The paired sera against the viruses used in this examination were provided by Dr S. K. R. Clark (sera from a volunteer infected with the W agent). Dr A. Z. Kapikian (sera from a chimpanzee infected with the Norwalk agent), Dr R. G. Wyatt (sera from a volunteer infected with the Hawaii agent), Dr. T. Konno (sera from a schoolboy infected with the Norwalk agent) and Dr S. Chiba (sera from a baby infected with calicivirus). In all of these paired sera, significant seroresponses in a homologous system have been confirmed by immune electronmicroscopy or radioimmunoassay blocking tests.

† Antibody coating of the 35-40-nm particles was assessed on a scale 0 to 4 .
}

were simultaneously or successively added to a convalescent serum from patient no. 20 in outbreak no. 5 . We found that even successive addition of the two distinct particles resulted in a formation of mixed aggregates (figs. 8a and b). A control experiment was done with the 35-40-nm particles and empty (H) particles of poliovirus type 1 (Mahoney strain). We were able to use the same serum from patient no. 20 in this control because it contained an adequate amount of antibody against the poliovirus $\mathrm{H}$ particles. The control experiment showed that successive addition of the two antigenically different particles formed separate aggregates, each composed of homogeneous antigenic particles (fig. 9), although their simultaneous application resulted in a very slight trapping of heterologous particles.

The reaction of guinea-pig antiserum, raised against the purified 35-40-nm particles, with the 15-20-nm empty particles was examined to confirm antigenic cross-reactivity between these two particles. The increase in titre of the immune serum against the 35-40-nm particles with time after immunisation is shown in table VI. A 1 in 400 dilution of the antiserum collected 49 days after immunisation could agglutinate the 15-20-nm empty particles, whereas the same dilution of pre-immunisation serum could not agglutinate the particles (figs. 10a and b).

Finally, antibodies eluted by acid dissociation from the aggregates of the 35-40-nm particles and their antiserum were examined for their reactivity against the 15-20-nm particles. A mixture of the purified 35-40-nm particles and their antiserum was incubated for 2 days at $4^{\circ} \mathrm{C}$. After the mixture was ultracentrifuged, the resultant precipitate was washed twice with $100 \mathrm{~mm}$ PBS by ultracentrifugation, and then subjected to acid dissociation ( $50 \mathrm{~mm}$ glycine$\mathrm{HCl}$ buffer, $p \mathrm{H} 2 \cdot 0$, for $40 \mathrm{~min}$ at $4^{\circ} \mathrm{C}$ ). The solution was again ultracentrifuged to remove the particles, and the supernate containing dissociated antibodies was adjusted to $p \mathrm{H} 7 \cdot 2$ with $0 \cdot 1 \mathrm{~N} \mathrm{NaOH}$. Antibodies thus obtained were 


\section{VIRUS ASSOCIATED WITH GASTROENTERITIS}
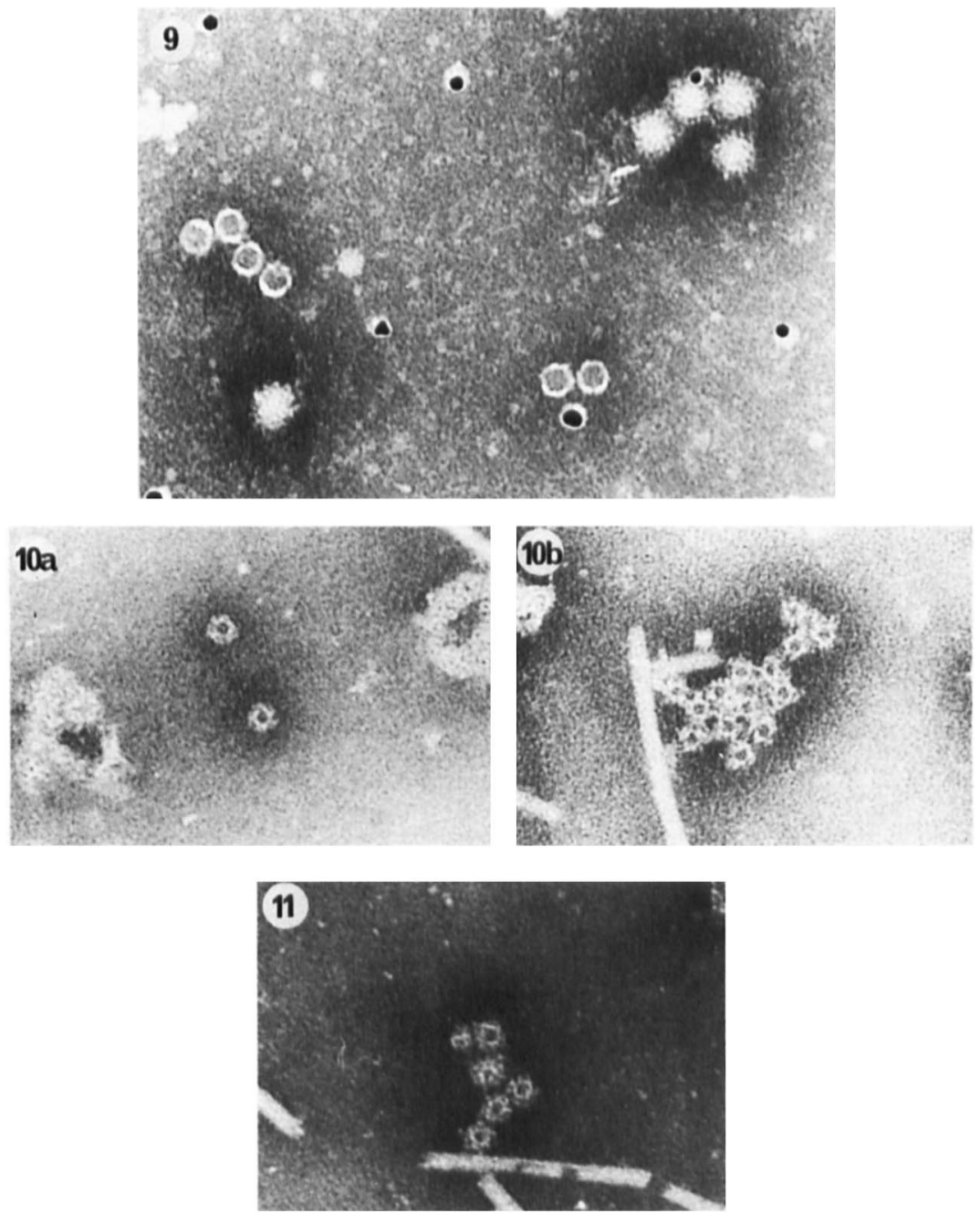

FIG. 9.-Two distinct aggregates each containing either poliovirus $\mathrm{H}$ particles or the 35-40-nm particles. The two types of particles were successively added to a convalescent serum (patient no. 20) from outbreak no. 5. PTA. $\times 126750$.

FIGS. 10a and b.--Reactions of the 15-20-nm "empty" particles with the guinea pig serum collected before (10a) or after (10b) immunisation with the 35-40-nm particles. PTA. $\times 126750$.

FIG. 11. The 15-20-nm "empty" particles agglutinated by the antibodies dissociated from the complexes between the $35-40-\mathrm{nm}$ particles and their antiserum. PTA. $\times 126750$. 


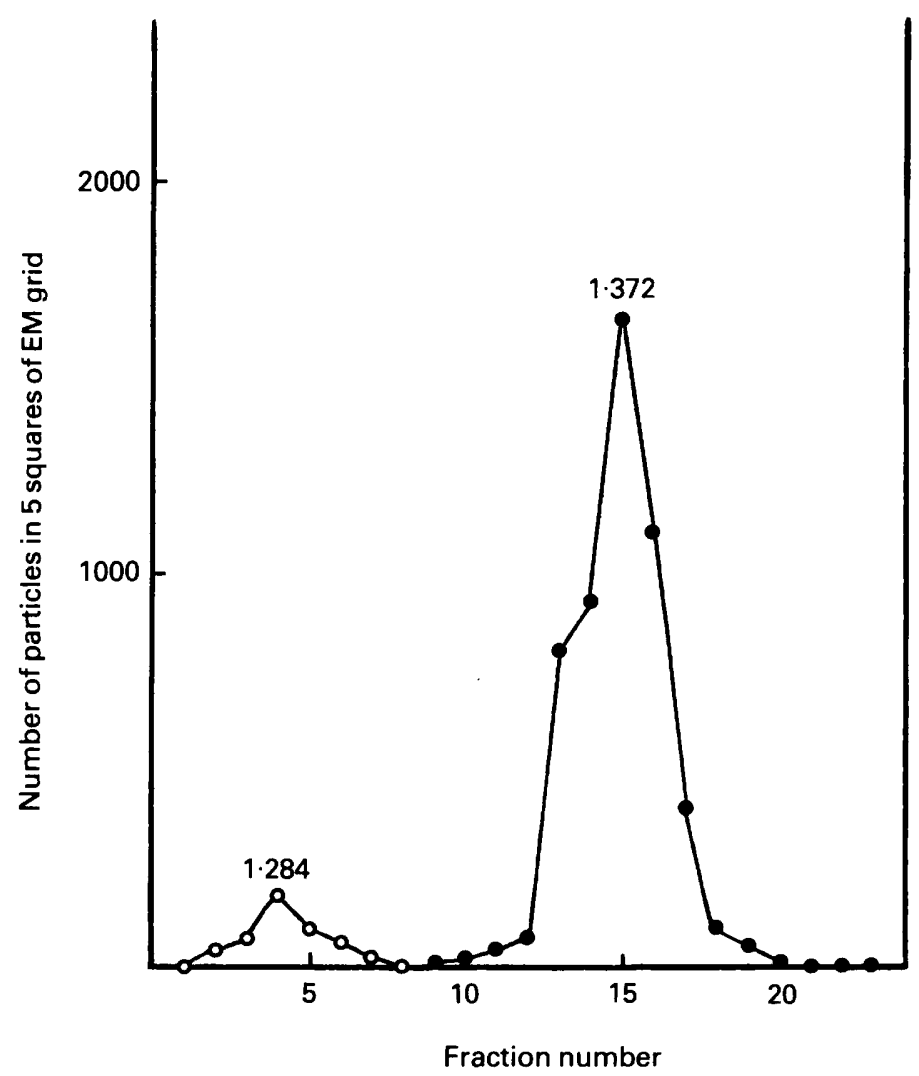

Fig. 6.-Isopycnic banding of the 15-20-nm "empty" particles (buoyant density 1.284) ( $\left.{ }^{\circ}-0\right)$ and the 35-40-nm particles (buoyant density 1.372) $(\bullet-\bullet)$ derived from a stool specimen (patient no. 20 in outbreak no. 5) in a $\mathrm{CsCl}$ density gradient.

\section{TABLE VI}

Titration of guinea-pig antiserum against the 35-40-nm particles by immune electronmicroscopy

\begin{tabular}{llll}
\hline $\begin{array}{c}\text { Dilution of } \\
\text { serum: } \\
1 \text { in }\end{array}$ & \multicolumn{3}{c}{$\begin{array}{c}28 \\
\text { days after } \\
\text { immunisation }\end{array}$} \\
\hline 8 & $0-1$ & 4 & 49 \\
25 & NT & 3 & 4 \\
100 & NT & 1 & 4 \\
400 & NT & 0 & 2 \\
1600 & NT & 0 & 0
\end{tabular}

$\mathrm{NT}=$ not tested.

* Antibody coating of the 35-40-nm particles was assessed on a scale of 0 to 4 .

+ The guinea-pig was boosted on the 35 th day after the first immunisation. 
incubated for $1 \mathrm{~h}$ at room temperature with the 15-20-nm empty particles. As shown in fig. 11, the antibodies eluted from the 35-40-nm particles agglutinated the $15-20-\mathrm{nm}$ particles.

\section{DisCUSSION}

The particles detected in the five separate outbreaks of gastroenteritis had almost the same size and morphology; they all measured 35-40-nm in diameter, and well delineated small capsomeres on the surface were readily observed. In each of the three outbreaks in which paired sera of patients and a sufficient amount of the 35-40-nm particles were obtained, infection with these particles was confirmed by significant antibody responses in patients against the particles from corresponding outbreaks. Furthermore, the results of IEM tests made with antigens from the outbreak and paired sera from other outbreaks suggested that the 35-40-nm particles observed in the five outbreaks might be related antigenically to one another although, in these heterologous combinations, significant seroresponses could not be observed in all cases examined (table IV). More precise clarification, by tests on more samples, of the antigenic relationships of the particles was hindered by shortage of antigen.

Besides the 35-40-nm particles, coronavirus-like particles and astroviruslike particles, both of which were seen in large numbers, were detected in stool specimens from the patients in outbreak no. 2. However, antibody responses to either of the particles were not found in paired sera from outbreaks nos. 3 and 4, despite the significant response of the same paired sera against the 35-40-nm particles. In addition, each of these two kinds of particle was detected in only one stool specimen of those from affected children in outbreak no. 2. It seems reasonable to conclude that neither of these two kinds of particles caused this outbreak.

Smaller particles, 15-20-nm in diameter and devoid of internal structure, were found in the aggregates predominantly composed of the 35-40-nm particles in IEM tests. Significant seroresponses against the smaller empty particles were demonstrated in IEM tests with particles purified by $\mathrm{CsCl}$ density-gradient centrifugation and paired sera from four patients in outbreak no. 5 (data not shown). Further, EM observation of the aggregates formed by the successive addition of the 35-40-nm particles and the smaller empty particles to a convalescent serum, and the reaction of antiserum against the 35-40-nm particles with the smaller particles suggested an antigenic relationship between these particles, though the structural correlation between them remains unknown. Recently, Woode and Bridger (1978) reported the detection of 33-nm particles sometimes accompanied by 18-nm smaller "empty" particles in stool specimens of a diarrhoeal calf. They referred to the 33-nm particle, bearing some resemblance to a calicivirus in size and morphology, as the "Newbury agent". In our study, the paired sera from a baby infected with calicivirus showed significant seroresponse with neither the 15-20-nm empty particles nor the 35-40-nm particles (table V). In addition, a comparison between the 35-40-nm particles and a strain of feline calicivirus in EM revealed 
a distinct difference in the morphological features (not illustrated). At present, therefore, we incline to the view that the 35-40-nm particles, including the Otofuke agent, are not caliciviruses although the two kinds of particles of different sizes in our study have an appreciable resemblance to the "Newbury agent" and its coexisting smaller particles.

Serological comparison of the 35-40-nm particles with some other candidate viruses for gastroenteritis by IEM suggested that the particles were not related to the Norwalk agent, the Hawaii agent, the W agent, or the caliciviruses. Recently, however, in solid-phase radioimmunoassay by Dr H. G. Greenberg of the National Institutes of Health, USA, the paired sera from the patients in outbreaks no. 1 (patient no. 4) and no. 5 (patient no. 23) are said to have shown seroresponses against the Norwalk agent, and the stool suspensions from outbreak no. 5 (patient no. 20) were positive for the Norwalk antigen, while paired sera from the patients in outbreaks no. 1 (patient no. 1), no. 3 (patient no. 13), no. 4 (patient no. 17) and no. 5 (patient no. 20) did not have significant seroresponses to the Norwalk antigen and stool suspensions from outbreaks no. 1 (patient no. 3), no. 3 (patient no. 13) and no. 4 (patient no. 17) were negative for the Norwalk antigen (Dr R. G. Wyatt, personal communication). Judging from the discrepancy between the results obtained in the NIH and in our laboratory, and from the difference in size and buoyant density between the Norwalk agent and our 35-40-nm particles, further studies seem necessary to determine whether the 35-40-nm particles, including the Otofuke agent, should be placed taxonomically with the Norwalk and related agents. Above all, physicochemical characterisation of these agents, including examination of the type and configuration of their nucleic acid, would have to be investigated first.

We thank Dr S. K. R. Clarke, Public Health Laboratory, Bristol, England, Drs A. Z. Kapikian and R. G. Wyatt, National Institutes of Health, USA, Dr T. Konno, Tohoku University, Japan, and Dr S. Chiba, Sapporo Medical College, Japan for supplying the paired sera against the gastroenteritis agents. We also thank Dr N. Sakurada, Hokkaido Institute of Public Health and Mr M. Kosugida, Department of Public Health, Hokkaido Prefectural Office for affording us an opportunity to examine sera and stool specimens of patients and for furnishing the information on the field surveys of outbreaks.

This study was supported in part by grants no. 437012 and no. 457159 from the Ministry of Education, Science and Culture of Japan.

\section{REFERENCES}

Appleton, H., Buckley, M., Thom, B. T., Cotton, J. L. And Henderson, S. 1977. Virus-like particles in winter vomiting disease. Lancet, $\mathbf{1}, 409$.

Appleton, H. AND Pereira, M. S. 1977. A possible virus aetiology in outbreaks of food-poisoning from cockles. Lancet, 1,780 .

Ashley, C. R., Caul, E. O. and Paver, W. K. 1978. Astrovirus-associated gastroenteritis in children. J. clin. Path., 31, 939.

Clarke, S. K. R., Cook, G. T., Egglestone, S. I., Hall, T. S., Miller, D. L., Reed, S. E., Rubenstein, D., Smith, A. J. AND TyrRell, D. A. J. 1972. A virus from epidemic vomiting disease. Br. med. J., 3, 86 .

DoLIN, R. 1978. Norwalk agent-like particles associated with gastroenteritis in human beings. J. Am. vet. med. Ass., 173, 615. 
Holmes, I. H. 1979. Viral gastroenteritis. Prog. med. Virol., 25, 1.

McSwiggan, D. A., Cubitt, D. AND MoORE, W. 1978. Calicivirus associated with winter vomiting disease. Lancet, $1,1215$.

Madeley, C. R. 1979. Viruses in the stools. J. clin. Path., 32, 1.

MADELEY, C. R. AND CosGROVE, B. P. 1975. Viruses in infantile gastroenteritis. Lancet, 2, 124.

Madeley, C. R. and Cosgrove, B. P. 1976. Caliciviruses in man. Lancet, 1, 199.

TAKaHaShI, E., Konishi, S. AND OGATA, M. 1971. Studies on cytopathogenic viruses from cats with respiratory infections. II. Characterization of feline picornaviruses. Jap. J. vet. Sci., 33,81 .

Taniguchi, K., Urasawa, S. and Urasawa, T. 1979. Virus-like particle, 35 to $40 \mathrm{~nm}$, associated with an institutional outbreak of acute gastroenteritis in adults. J. clin. Microbiol., $10,730$.

Thornhill, T. S., Wyatt, R. G., Kalica, A. R., Dolin, R., Chanock, R. M. and Kapikian, A. Z. 1977. Detection by immune electron microscopy of 26- to 27-nm viruslike particles associated with two family outbreaks of gastroenteritis. J. infect. Dis., 135, 20.

Urasawa, T., Urasawa, S. AND TANIGUCHI, K. 1979. Reactivity of neutralizing antibodies with different specificities to $\mathrm{H}$ particles of poliovirus. Microbiol. Immunol., 23, 651 .

WOODE, G. N. AND BRIDGER, J. C. 1978. Isolation of small viruses resembling astroviruses and caliciviruses from acute enteritis of calves. J. med. Microbiol., 11, 441.

YoungneR, J. S. 1954. Monolayer tissue cultures. I. Preparation and standardization of suspensions of trypsin-dispersed monkey kidney cells. Proc. Soc. exp. Biol. Med., 85, 202. 